\title{
PENDIDIKAN MIGRASI AMAN: MEMBANGUN KEKUATAN MELALUI PENGETAHUAN
}

\section{EDUCATING SAFE MIGRATION: BUILDING POWER THROUGH KNOWLEDGE}

\author{
${ }^{1)}$ Nurul Azizah Zayzda, ${ }^{2}$ Sri Wijayanti \\ 1,2 Jurusan Hubungan Internasional, Universitas Jenderal Soedirman, \\ Jl. H.R. Boenyamin No. 993 Purwokerto \\ Email: nurul.zayzda@unsoed.ac.id
}

\begin{abstract}
ABSTRAK
Urgensi dari pembelajaran migrasi aman berangkat dari masalah yang dihadapi migran yang cenderung dipandang semata sebagai objek dari kebijakan dan memiliki posisi lemah sebagai orang asing di negara tujuan. Migrasi tidak aman yang dihadapi masyarakat Indonesia telah menyebabkan berbagai kasus seperti human trafficking, pelanggaran kontrak, beban kerja yang berlebihan dan masalah lainnya seperti overstay atau hilang kontak dengan keluarga dan agen akibat pengetahuan yang lemah mengenai migrasi. Dalam tulisan ini dijabarkan mengenai pentingnya pemahaman mengenai migrasi aman dan cara yang telah dilakukan penulis untuk menumbuhkan pengetahuan ini melalui kegiatan pelatihan peer educator untuk tersebarluasnya pemahaman migrasi aman. Metode pelatihan peer educator untuk pembelajaran migrasi aman ini telah diterapkan di SMK Swagaya 1 Purwokerto, Banyumas dengan latar belakang sejumlah lulusan sekolah ini sebelumnya telah bekerja di luar negeri sebagai pekerja migran. Tren seperti ini terus berlanjut sehingga dibutuhkan pelatihan untuk meningkatkan pengetahuan siswa mengenai migrasi aman. Berikut adalah beberapa hasil yang didapatkan dari pelatihan. Pertama, pelatihan ini telah membekali sejumlah siswa dengan pengetahuan dasar mengenai migrasi aman untuk pekerja dan mengenai hak-hak pekerja migran dilihat dari hasil post-test. Kedua, pelatihan ini telah memicu inisiatif siswa peserta pelatihan untuk melakukan pengajaran mengenai migrasi aman dengan berbagai metode di lingkungan sekolah, yakni pengajaran langsung dan menyelenggarakan lomba majalah dinding sekolah yang diikuti semua kelas dengan tema migrasi aman. Ketiga, dengan adanya lomba majalah dinding, seтua kelas terlibat secara aktif dalam mengumpulkan bahan bacaan mengenai migrasi aman sehingga pengetahuan mereka sendiri meningkat. Secara umum dapat disimpulkan bahwa pelatihan ini meningkatkan pengetahuan siswa SMK Swagaya 1 Purwokerto mengenai migrasi aman dan hak-hak pekerja migran.
\end{abstract}

Kata kunci : Migrasi Aman, Pekerja Migran, Peer Educator, Pengajaran, Hak-Hak Pekerja Migran.

\section{ABSTRACT}

The urgency of learning safe migration departs from migratory-dependent issues where migrants are only seen as objects of policy and have a weak position as foreigners in the destination country. The unsafe migration that is experienced by huge number of Indonesian migrant workers has led to various cases such as human trafficking, contract contracting, overwork and other problems such as overstay or lost contact with family and agents due to weak knowledge of migration. This paper will describe the urgency of safe migration and the activity that the author has done to promote this knowledge among group of students, where becoming a migrant worker is a potential future plan. The method for the solution was peer educator training aimed to spread the understanding of safe migration. The peer educator training method for safe migration learning has been implemented at SMK Swagaya 1 Purwokerto, Banyumas given that in the past a number of graduates from the school having previously worked abroad as migrant workers. Such trends continue, so training is needed to improve students' knowledge on safe migration and workers' rights. Here are some of the results obtained from the training. First, the training has provided the students participating in training with basic migration knowledge for employment and discussed the rights of migrant workers. 
Second, this training has motivated aforementioned students to teach the peer students on safe migration through a direct presentation and organizing school events that are followed by all classes with the theme of secure migration. Third, with the school magazine competition, all classes were involved in collecting information on safe migration, improving the wider groups of students knowledge. In general, it can be concluded that the training has improves students of SMK Swagaya 1 Purwokerto knowledge on safe migration and workers' rights.

Keywords: Safe Migration, Migrant Workers, Peer Educators, Teaching, Migrant Worker Rights.

Submitted : 31 Oktober 2017

\section{PENDAHULUAN}

Migrasi aman (safe migration) secara umum merujuk kepada proses migrasi yang sesuai prosedur dan dilakukan dengan cara aman dan melalui jalur-jalur yang teratur (Inter-Agency Task Force for Financing Development, 2016). Kampanye migrasi aman telah berlangsung secara global, di antaranya untuk memastikan para migran memiliki pengetahuan yang memadai mengenai prosedur migrasi yang sesuai aturan, dan dapat menjalani hidup yang normal di Negara tujuan migrasinya. Hal-hal yang dapat menyebabkan migrasi tidak aman antara lain adalah bila migran tidak memenuhi syarat dokumendokumen yang diperlukan untuk masuk ke Negara lain, seperti visa dan passport dan dokumen lain yang menjadi syarat migrasi pekerja.

Menurut Però, (2011) selama berada dinegara tujuan tempat bekerja, pekerja migran rentan menghadapi perlakuan tidak adil, tidak dipenuhi hak-haknya atau diskriminasi karena terdapat pandangan yang cenderung meminggirkan mereka. Menurut Wimmer dan Glick-Schiller (2009), permasalahan migrasi yang ada selama ini tidak lepas dari metodologi yang digunakan penstudi migrasi dalam mengumpulkan data, menganalisis dan membicarakan isu-isu migrasi. Permasalahan metodologis ini ia sebut nasionalisme metodologis (methodological nationalism) yaitu sebuah pandangan yang melekatkan migran pada identitas nasionalnya yang bersifat asing bagi masyarakat tuan rumah tempatnya bekerja. Akibatnya, migran, khususnya disini adalah kelompok pekerja migran dan pengungsi terusterusan dipandang sebagai orang asing yang tidak diterima secara utuh di negara tujuan.

Ketidakutuhan ini terlihat dari bentuk keterbatasan hak-hak migran yang didapatkannya.Sebagai pendatang yang bekerja di posisi yang bersifat sementara, terdapat berbagai keterbatasan yang dihadapi oleh seorang pekerja migran. Beberapa masalah yang paling umum menimpa pekerja migran Indonesia yang didata oleh BNP2TKI di antaranya adalah masalah gaji yang tidak dibayar, pekerjaan yang tidak sesuai kontrak, PMI yang sakit saat diluar negeri, proses perekrutan ilegal calon PMI dan sebagainya (BNP2TKI, 2015). Sementara itu Kabupaten Banyumas merupakan kabupaten dengan jumlah tenaga kerja migran yang tinggi. Banyumas termasuk dalam 25 besar kabupaten/kota se Indonesia yang banyak menempatkan pekerja Migran Indonesia (PMI) ke luar negeri (BNP2TKI, 2015).

Perlindungan terhadap pekerja migrandiatur melalui hukum internasional. Hukum internasional yang paling utama disini adalah Konvensi Internasional mengenai Perlindungan Hak Tenaga Kerja Migran dan Anggota Keluarganya. Namun tidak ada dari Negara penerima utama di ASEAN yang menandatangani konvensi internasional tersebut (ILO dan ADB, 2014). Di level ASEAN sementara itu terdapat Deklarasi mengenai Perlindungan dan Peningkatan Hakhak Tenaga kerja Migran yang disepakati pada tahun 2007. Namun sifat implementasi ini cenderung dilakukan oleh negara perorangan 
ketimbang bersama-sama sebagai satu komunitas.

Bentuk-bentuk hukum dan kebijakan terkait pekerja migran yang diterapkan negaranegara ASEAN (ILO dan ADB, 2014) menunjukkan bagaimana sulitnya mencapai jaminan perlindungan bila hanya diharapkan dari kemauan politik negara. Seperti dituliskan Piper (2004) pekerja migran di ASEAN adalah kelompok yang "dibutuhkan, namun tidak diinginkan". Dalam sistem negara-bangsa yang melihat migran sebagai sosok asing atau berada diluar sistem, kecenderungannya disini adalah normalisasi bentuk-bentuk marjinalisasi ini melalui hukum nasional, misalnya hukum imigrasi, hukum ketenagakerjaan dan hukum mengenai perlindungan sosial. Ditambah dengan bentuk-bentuk hukum dan kebijakan yang diterapkan negara-negara ASEAN menunjukkan bagaimana sulitnya mencapai jaminan perlindungan bila hanya diharapkan dari kemauan politik negara.

Disamping lemahnya hukum yang melindungi hak-hak pekerja migran, perlu pula diperhatikan faktor internal yakni pengetahuan dari calon PMI sebelum berangkat dan ketika bekerja di luar negeri. Pengetahuan yang dimaksud meliputi prosedur migrasi aman, hukum di negara tujuan, serta apa saja yang menjadi hak-hak pekerja migran. Upaya peningkatan pengetahuan mengenai ketenagakerjaan dan migrasi aman seperti yang dilakukan dalamprogram pengabdian yang telah dilakukan penulis merupakan bagian dari upaya mempersiapkan masyarakat mengenai kehidupan transnasional sebagai seorang migran. Disini, masyarakat diberi kesadaran semenjak dini mengenai posisi buruh migran seperti dijelaskan Glick-Schiller (2010: 127) bahwa dengan menjadi seorang migran, seseorang bukan menjadi sekedar orang asing di tanah bangsa lain, namun sesungguhnya mereka menghubungan ranah lokal, merujuk kepada keseharian mereka sebagai pekerja, dengan proses global yakni sistem kapitalisme.

Dalam tulisan ini akan dibahas lebih jauh mengenaiprogram pelatihan peer educator untuk pembelajaran migrasi aman serta hak-hak pekerja migran. Pelatihan ini telah dilakukan di salah satu sekolah di Purwokerto yakni SMK 1 Swagaya Purwokerto. SMK Swagaya 1 Purwokerto berlokasi di Kabupaten Banyumas, Kecamatan Purwokerto. Bidang Kejuruan di sekolah ini adalah Akuntansi, Manajemen, Teknik Mesin dan Multimedia. Selama beberapa tahun terakhir, sebagian lulusan dari SMK Swagaya 1 Purwokerto bekerja di luar negeri sebagai Pekerja Migran Indonesia (PMI). Mereka bekerja di negara-negara tetangga seperti Malaysia dan Singapura dengan skema kontrak/outsourcing di sektor-sektor industri sebagai buruh. ${ }^{1}$ Dengan skema kontrak, para lulusan ini tidak memiliki pekerjaan tetap dan rentan menjadi pengangguran. Dalam diskusi dengan berbagai kesempatan dengan pihak sekolah, ditemukan potensi untuk terus berlanjutnya tren ini.

Hal ini menunjukkan masalah riil sekolah ini yakni para siswa terus terpapar dengan potensi menghadapi masalah sebagai pekerja migran di masa depan. Salah satu bentuk perlindungan terhadap pekerja migran adalah pada pencegahan terjadinya masalah. Disini, masih tidak mungkin untuk mencegah lulusan bekerja di luar negeri, namun sangat mungkin untuk memberikan pendidikan kepada seluruh populasi sekolah mengenai migrasi aman. Dengan permasalahan tersebut, SMK Swagaya 1 Purwokerto memiliki urgensi sebagai target pelatihan migrasi aman.

Tujuan pelatihan adalah mengajarkan pengetahuan mengenai migrasi aman dan hakhak pekerja kepada sejumlah siswa yang berpotensi menjadi peer educator. Dengan menjadi peer educator, siswa-siswa ini dapat memastikan bahwa pengetahuan tadi akan didapatkan siswa lainnya di lingkungan sekolah.

\section{METODE}

Dikarenakan pelatihan ini bersifat preventif atau mengurangi kemungkinan

\footnotetext{
${ }^{1}$ Wawancara dengan Kepala Sekolah
} 
terjadinya masalah yang dihadapi PMI di masa depan, mitra adalah siswa SMK Swagaya 1 Purwokerto yang memiliki kemungkinan akan bekerja di luar negeri, seperti halnya sejumlah lulusan sekolah ini sebelumnya. Pendidikan migrasi aman dimaksudkan untuk siswa SMK Swagaya 1 mulai dari tingkat $\mathrm{X}$ hingga tingkat akhir XII.Secara khususnya, dalam pelatihan ditentukan sejumlah 35 siswa yang aktif di organisasi kesiswaan seperti OSIS dan Majelis Permusyawaratan Kelas (MPK).

Dikarenakan permasalahan yang digarisbawahi disini adalah krusialnya pengetahuan mengenai prosedur migrasi aman dan hal-hal yang menjadi hak pekerja migran, serta instansi yang berwenang atau memiliki kemampuan membantu migran, maka solusi yang tepat harus melibatkan aktivitas diseminasi informasi. Aktivitas pemberian informasi ini sudah dilakukan oleh pemerintah daerah dan pihak-pihak lain yang terkait, namun masih dibutuhkan upaya lebih lanjut untuk memastikan informasi ini benar-benar tersebar.

Pelatihan adalah penyelesaian yang baik, namun pengabdian ini bermaksud untuk melampaui target-target pelatihan. Dalam pengabdian ini, pelatihan dilakukan sekaligus untuk memastikan para siswa dapat turut secara aktif menyebarkan informasi migrasi aman ini kepada lingkungannya, terutama mereka yang kemungkinan menjadi calon PMI di masa depan. Dengan demikian, pemecahan masalah yang dilakukanmitra adalah pelatihan peer educator yang memberikan informasi mengenai migrasi aman dan memberi kesadaran siswa sebagai 'agen' informasi migrasi aman. Dari pelatihan peer educator ini, informasi mengenai migrasi aman dan pengetahuan mengenai kehidupan migran dapat tersebar ke kalangan siswa khususnya dan masyarakat luas pada umumnya. Ke depannya, pengetahuan ini dapat membantu mengurangi intensitas migrasi tidak aman yang dihadapi oleh PMI.

Metode yang digunakan dalam pengabdian kepada masyarakat ini adalah pelatihan peer educator. Disini diberikan informasi lengkap mengenai prosedur migrasi aman, termasuk pihak-pihak yang akan terlibat dalam migrasi yang aman, serta indikator migrasi tidak aman mulai dari tahap persiapan, pemberangkatan dan periode bekerja. Di samping itu, diberikan pemahaman mengenai peran yang bisa diambil siswa sebagai peer educator, dan dilakukan diskusi mengenai metode-metode apa yang dapat digunakan siswa untuk turut menyebarkan informasi migrasi aman. Mitra berpartisipasi dan bertindak sebagai peserta aktif. Tim pelaksana kegiatan sebagai tim penyuluh sekaligus sebagai pendamping dalam seluruh kegiatan pelatihan sertatindak lanjut yang telah direncanakan. Kegiatan pengabdian telah dilakukan dalam kurun waktu bulan April 2017-Oktober 2017 meliputi persiapan hingga evaluasi.

Kegiatan pelatihan peer educator dilaksanakan di SMK Swagaya 1 Purwokerto pada bulan Juni 2017. Pelatihan dilakukan dengan beberapa aktivitas, yakni:

1. Pemberian materi/pengarahan mengenai migrasi aman

2. Roleplay yang diperankan siswa peserta pelatihan

3. Pembuatan Rancangan Tindak Lanjut oleh siswa peserta pelatihan

Pelatihan dilakukan dengan metode ceramah, pendalaman materi melalui roleplay dan penyusunan Rancangan Tindak lanjut. Untuk pengarahan materi kepada siswa, tim mengundang Dr. Tyas Retno Wulan, Ketua Pusat Penelitian Gender dan Anak dan Pengabdian masyarakat (PPGA-PM) Universitas Jenderal Soedirman. Dr. Tyas Retno Wulan memberikan materi yakni prosedur migrasi aman dan hak-hak pekerja migran. Setelah menerima materi, siswa kemudian melakukan pendalaman materi dengan metode roleplay. Dalam sesi roleplay, siswa dibagi kedalam beberapa kelompok dan diminta untuk bermain peran dengan beberapa topik yang berbeda-beda. Tema-tema yang 
diberikan dalam roleplay ini adalah sebagai berikut:

1. Memahami prosedur migrasi aman. Siswa dapat mengulang kembali keseluruhan prosedur migrasi aman, serta memperagakan kemungkinankemungkinan menghadapi proses yang tidak sesuai prosedur yang merugikan atau membahayakan calon pekerja.

2. Mengenali agen perekrutan illegal. Siswa dapat mengidentifikasi dan memeperagakan bagaimana prekrutan ilegal bekerja, modusnya dan bagaimana harus menghadapinya.

3. Mengenali budaya dan hukum negara tujuan. Siswa dapat memahami bahwa pengetahuan ini sangat dibutuhkan, dengan memperagakan contoh dampaknya bila tidak memahami ini.

4. Mengenali hak-hak pekerja migrant. Siswa dapat memahami hak-hak pekerja migran yang sudah diatur dalam hukum internasional dan apa yang dapat dilakukan saat mendapati situasi dimana hak-hak tidak dipenuhi.

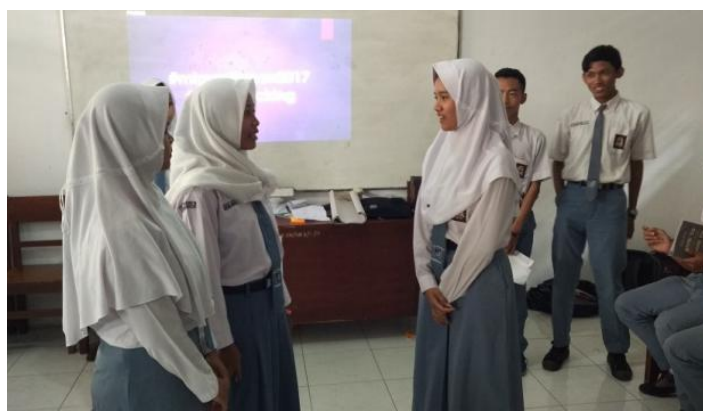

Gambar 1. Roleplay untuk Pendalaman Materi

Setelah pendalaman materi, siswa diwajibkan untuk membuat Rencana Tindak Lanjut (RTL) secara mandiri. Rencana Tindak Lanjut adalah daftar aktivitas-aktivitas yang akan dilakukan siswa untuk lebih jauh membagikan pengetahuan migrasi aman kepada temanteman atau lingkungannya. Berikut adalah rencana tindak lanjut yang disusun siswa peserta pelatihan:
1. Mengajarkan migrasi aman kepada temanteman di sekolah secara langsung

2. Membagikan informasi migrasi aman melalui media sosial

3. Memasukkan materi migrasi aman dalam pelatihan LDK OSIS

4. Memasukkan materi migrasi aman dalam kegiatan PLS pada masa orientasi siswa baru

5. Memasang poster di tempat yang bisa dilihat siswa

6. Mengadakan lomba mading antar kelas pada Perayaan Ulang Tahun sekolah.

Capaian pelatihan peer educator ini diukur melalui pre-test dan post-test serta pelaksanaan rencana tindak lanjut ini.

\section{HASIL DAN PEMBAHASAN}

Dari pre-test dan post-test yang dilaksanakan, ditemukan peningkatan pengetahuan siswa mengenai migrasi aman. Pada pre-test, 100 per sen siswa belum dapat menjawab 80 per sen pertanyaan yang diberikan dengan benar. Kemudian pada post-test, 90 per sen siswa sudah menjawab minimal 80 per sen pertanyaan dengan benar. Pertanyaanpertanyaan yang diberikan mencakup wawasan siswa mengenai definisi migrasi aman, prosedur migrasi aman, macam-macam hak PMI, definisi human trafficking, pelaku human trafficking, korban human trafficking, dan pendapat mereka mengenai peran siswa dalam pencegahan masalah-masalah yang dihadapi PMI. Pada pre-test, seluruh siswa tidak dapat menjawab pertanyaan secara substantif walaupun mereka dapat memperkirakan mengenai peran siswa. Pada post-test siswa telah dapat menjawab secara tepat pertanyaan-pertanyaan tersebut.

Dalam tahap pelaksanaan rencana tindak lanjut, tim melakukan pendampingan lebih lanjut khususnya pada empat kegiatan yakni; pengajaran migrasi aman, membagi informasi melalui media sosial, memasang poster serta mengadakan lomba majalah dinding antar kelas. 
Pengajaran migrasi aman merupakan praktek siswa SMK peserta pelatihan untuk mengajarkan materi Migrasi Aman kepada teman-teman di sekolah. Pengajaran dilakukan dengan metode presentasi dimana siswa menyusun materi presentasi bersama-sama sesuai pengetahuan yang sudah didapatkan dalam pelatihan dan memaparkannya di kelas secara mandiri dengan Tim Pengabdian sebagai pendamping persiapan dan observer saat pelaksanaan. Penyusunan materi bersamasama ditujukan agar terdapat kesepakatan mengenai tujuan pengajaran serta keseragaman informasi.

Dari diskusi bersama siswa maka disepakati tujuan pengajaran ini adalah untu memberikan informasi mengenai prosedur migrasi aman untuk pengetahuan apabila terpaksa bekerja diluar negeri dan memberikan pengetahuan mengenai hak-hak pekerja migran. Pengajaran ini tidak ditujukan untuk mendorong siswa SMK untuk menjadi pekerja di luar negeri, namun apabila dalam situasi yang tidak bisa dihindarkan dan siswa memilih bekerja diluar negeri, diharapkan mereka telah dibekali dengan pengetahuan migrasi aman yang baik. Disamping itu diskusi dalam pengajaran ini diharapkan memberikan gambaran masalah apa yang mungkin ditemui saat bekerja diluar negeri dan bagaimana harus menghadapinya. Pada dasarnya disini diajarkan bahwa setiap pekerja migran harus menjaga komunikasi dengan keluarga dan komunitas pekerja migran Indonesia di tempatnya bekerja.

Setelah dilakukan pengajaran di kelas, hasil pengabdian diukur dari pelaksanaan rencana tindak lanjut berikutnya, yakni lomba majalah dinding kelas dengan tema migrasi aman. Tim pengabdian terlibat secara aktif dalam kegiatan ini. Penyelenggaraan lomba mading ini menunjukkan hasil dari pelatihan dengan ketercapaian berupa pelaksanaan pengajaran migrasi aman oleh peer educator sesuai dengan rencana tindak lanjutnya, meningkatnya pengetahuan siswa peserta lomba mengenai migrasi aman melalui penggalian pengetahuan migrasi aman secara mandiri; dan meningkatnya pengetahuan seluruh siswa di sekolah mengenai migrasi aman dengan adanya majalah dinding yang dipajang di kelas masing-masing.

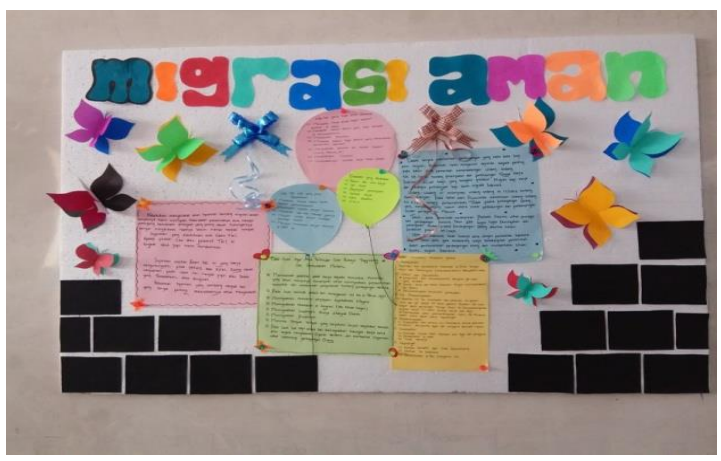

Gambar 3. Lomba Majalah Dinding antar kelas dengan tema Migrasi Aman

Kegiatan pelatihan ini telah menyentuh masalah metodologis yang disampaikan Wimmer dan Glick-Schiller (2002) dengan memberikan pemahaman kepada siswa bahwa menjadi pekerja walaupun bukan di negara sendiri tidak menghilangkan hak-hak dasarnya. Mereka berhak untuk bekerja dan diperlakukan secara manusiawi oleh pemerintah, agen dan pemberi pekerja. Di masa depan, apabila ada siswa yang bekerja sebagai PMI, mereka akan mengikuti prosedur yang benar agar terhindar dari masalah dan dapat memahami dimana hak-haknya dikompromikan oleh agen atau pemberi pekerjaan.

Lebih jauh lagi, pelatihan semacam ini memberikan kekuatan atau posisi yang lebih kuat bagi PMI dimana ia berada. Selama ini posisi PMI cenderung lemah apakah dalam konflik dengan pemberi pekerja, atau menjadi korban penipuan dikarenakan kurangnya pengetahuan mengenai migrasi aman. Pelatihan ini secara khusus bermaksud memperkuat posisi PMI dengan membekali mereka dengan pengetahuan bahkan sebelum mereka memutuskan menjadi PMI.

\section{SIMPULAN}


Pelatihan peer educator dalam hal ini membantu kesiapan menjalankan migrasi aman serta menumbuhkan kesadaran masyarakat luas mengenai hak pekerja migran sebagai aktor global. Masa depan migrasi dalam sudut pandang tulisan ini adalah migrasi dipandang sebagai suatu proses global yang manusiawi. Dikarenakan masalah ekonomi di tingkat lokal tidak dapat dilepaskan dari masalah ekonomi global, sudah sewajarnya apabila para pekerja migran juga dipandang sebagai aktor global, bukan sebagai orang asing akibat melekatnya batasan territorial negara-bangsa. Pembahasan mengenai mereka adalah pembahasan mengenai hak-hak dasarnya sebagai manusia. Negara, baik itu negara tujuan maupun negara asal disini berperan untuk menyediakan konteks kebijakan yang manusiawi ini. Disisi lain, gerakan yang bersifat bottom-up berfungsi untuk meningkatkan kesadaran dan pengetahuan yang pada akhirnya tidak hanya memberikan kesiapan teknis para migran namun juga mengubah retorika mengenai migran pada ahirnya. Ke depannya, migrasi akan terjadi bukan lagi dilihat sebagai akibat tekanan ekonomi yang membuat seseorang melakukan apapun dengan menerima segala risiko, namun sebagai hak asasi seseorang untuk memperbaiki kehidupannya.

\section{DAFTAR PUSTAKA}

Badan Nasional Penempatan dan Perlindungan Tenaga Kerja Indonesia. (2015). Data Penempatan dan Perlindungan Tenaga Kerja Indonesia tahun 2015 (Posisi Satu Januari s.d. 31 Oktober).

Glick-Schiller, N. (2010). Global Perspective on Transnational Migration: Theorising migration without Methodological Nationalism.In R. Baubock \& T. Faist (Eds). Diaspora and Transnationalism: Concepts, Theories, and Methods. (109-130). Amsterdam: Amsterdam University Press.

\author{
Integration For Better Jobs And \\ Shared Prosperity. Bangkok: \\ International Labour Organization \\ and Asian Development Bank
}

Inter-Agency Task Force for Financing Development. 2016. Promoting Safe Migration, diunduh dari https://developmentfinance.un.org/promot ing-safe-migration pada Maret 2017

Però, D. (2011). Migrants' Practices of Citizenship and Policy Change. In C. Shore., S. Wright, \& D. Però (Eds). Policy Worlds: Anthropology and the Analysis of Contemporary Power. 244-263. New York, Oxford: Berghahn Books.

Piper, N. (2004). Rights of Foreign Workers and the Politics of Migration in South East and East Asia. International Migration, 42(5), 71-97.

Wimmer, A. \&Glick-Schiller, N. (2002). Methodological Nationalism: NationState Building, Migration and Social Sciences. Global Networks, 2(4), 301334.

ILO and ADB. (2014). Asean Economic

Community 2015: Managing

